\title{
The Impact of Indonesian Economic Growth on Tax Revenue Ratio, Goverment Expenditure Ratio and Macroeconomic Aspects in The Period of 1997-2016
}

\author{
Rosalendro Eddy Nugroho
}

\begin{abstract}
The objective of the research is to recommend the model of Indonesian Economic Growth in terms of Tax Revenue Ratio, Government Expenditure Ratio, Gini Ratio and Macroeconomic Aspect over the period 1997-2016. The results will be published in reputable journals. The objectives of the research are 1) To analyze the effect of the Revenue Ratio, Inflation Rate, Government Expenditure Ratio, Gini Ratio, Labor Force, Interest Rate of Bank Indonesia and Rupiah Exchange Rate Change to Indonesia Economic Growth Rate over the period 1997 - 2016, 2); Analyzing the most powerful factors affect Indonesia's Economic Growth on Tax Revenue Aspects, Government Expenditures, Gini Ratios and Macroeconomics over the period 1997-2016. Some of the analytical tools used are Multiple Regression Equations with the Multicollinearity Test, Heterocedasticity Test, Autocorrelation Test because if there is a deviation then the $t$ test and $F$ test done previously become invalid. The research stages are literature study and data retrieval from several media. Outline of research in the form of international journal publications. The results of the study indicated that the Government Expenditure Ratios and Interest Rates of Bank Indonesia influence significantly to the economic growth of Indonesia. The Government Expenditure Ratio has a positive impact while the Interest Rate of Bank Indonesia has a negative impact on Indonesia's economic growth.
\end{abstract}

Index Terms - Product Domestic Bruto,Tax Ratio, Inflation Rate,Goverment Expenditure.

\section{INTRODUCTION}

Recently, the issue of economic growth is very strategic because it is associated with the people's welfare. Foreign countries are the ones which have a very important role in the domestic economic growth in addition to other factors, judging from the economic activities namely: domestic and foreign exports and imports, direct investment into Indonesia. These macroeconomic activities are essential, not only to improve domestic economic products but also, in particular, to increase employment opportunities which are growing (Nugroho,RE,2017)

Economic growth is one very important indicators in assessing economic performance, especially to conduct an analysis of the economic development of a country or a regional authority. Economy is experience growth if the production of goods and services increases from the previous year. Thus, economic growth indicates the extent to which economic activity can generate additional income or welfare for a given period of time. Income taxes from growing society may affect the government's revenue from the tax sector (Nugroho,RE, 2017)

Inflation is the process of price rising prevails in an economic activity. Inflation rate is a percentage rate of goods price increase within a certain period of time). The higher the rate of inflation it will result in a declining economic growth that later on increase the number of unemployement. In addition, it is necessary to regulate government spending avoid overabundance, if it exceeds it will impact on the budget deficit so that strict supervision is required. (Mankiw, 2007).

Based on table 1.0 it exhibits the level of Economic Growth in Indonesia since the end of the economic crisis in 1997-1998, the rate of Economic Growth moving slowly but surely moving from the negative two-digit situation $(-14.2 \%$ in 1998) in the spand of thirteen (13) years the highest range occurred in 2011, Indonesia's economic growth reached a peak to $6.54 \%$ by applying various economic policies from Habibi era to Susilo Bambang Yudhoyono with the aim of enhancing a positive and relatively stable trend of the national economic growth (BPS Indonesia, 2016).

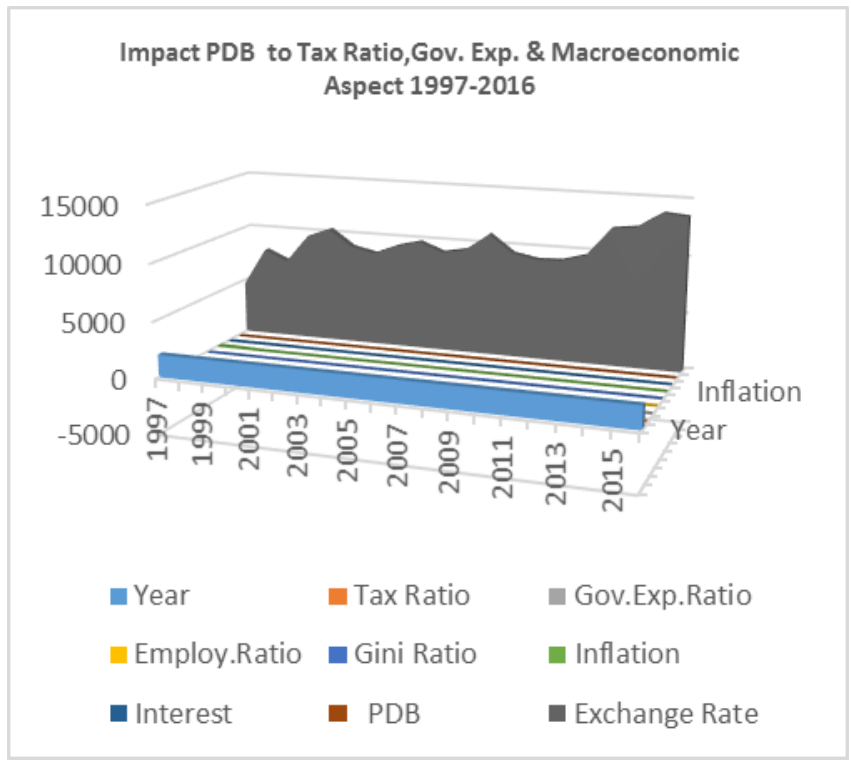

Fig. 1. Macroeconomics Aspects, Gini Ratio, Inflation, Interest 1997 to 2016 . Source: BPS (2017) 


\section{LITERATUR REVIEW}

According to Arsyad (2014) economic growth is defined as the increase in Gross Domestic Product / Gross National Income regardless of the high or low of population growth or if there are changes in economic structure. The above thinking can be explained by the income from the tax Sector, Bank of Indonesia interest rates, Government Expenditure Arrangements, inflation rate control and the the increasing labor force which will affect the volume of Indonesia's Economic Growth.

Human capital is a collection of investments yielded in our community. The most important type of human capital is education. Like all other types of capital, education reflects an expenditure of resources at one point in time which is subjected to increase future productivity. However, unlike other forms of investment, investment in education is bound to one who wishes to gain leverage on one's potential (Mankiw, 2007).

When one decides to take a job, wages are only one of the many attributes he / she considers. Some are fun, safe and while others are heavy, boring and dangerous jobs. A better job feature is not related to wage, many are willing to do the job at small wage. In other words, the supply of labor for a safe, easy and fun job is much greater than the labor supply for a tough, boring and dangerous job. The result is that favourite jobs tend to have a lower wage balance than unfavorable ones. People use the term compensating differential to refer to the job characteristics irrelevant to wage, this balancing difference is found in many economic activities (Arsyad, 2014).

\section{A. Formulation of The Problem}

Indonesia economic growth is a fluctuating economic phenomenon which is influenced by global economy besides also supported by competence and stability of domestic economy in which economic indicators can be monitored and supervised by some government institutions. Indonesia's economic growth is influenced by various factors such as Gini Ratio, Government Expenditure Ratios, Inflation Rate, Interest Rate of Bank Indonesia, Tax Ratio, Labor Force Change and Dollar Exchange Rate over Rupiah.

On the basis of the above problems then the research questions to be addressed in this study are:

1. What is the effect of Gini Ratio, Government Expenditure Ratios, Inflation Rate,Interest Rate of Bank Indonesia, Tax Ratio, Labor Force Change and Dollar Exchange Rate against Rupiah against Indonesia Economic Growth over the period 1997 - 2016 ?

2. What factors are most strongly influenced by the Indonesian economic growth for the variables; Gini Ratio, Government Expenditure Ratios, Inflation Rate, Interest Rate of Bank Indonesia, Tax Ratio, Labor Force Change and Dollar Exchange Rate against Rupiah over the period 1997 - 2016 ?

\section{B. Research Purposes}

Based on the background and formulation of the above problems, the objectives to be achieved in this research are:

1). Analizing the effect of Gini Ratio, Government
Expenditure Ratios, Inflation Rate,Interest Rate of Bank Indonesia, Tax Ratio, Labor Force Change and Dollar Exchange Rate to Indonesia Economic Growth over the period 1997 - 2016 ?.

2). Analizing which factors have the most influence on the Indonesian economic growth for variables; Gini Ratio, Government Expenditure Ratios, Inflation Rate, Interest Rate of Bank Indonesia, Tax Ratio, Labor Force Change and Dollar Exchange Rate against Rupiah over the period 1997 2016 ?

\section{METHOD}

The research method used in this study is a causal method that aims to examine the effect of Indonesia's Economic Growth over the period 1997 - 2016 toward Gini Ratio, Government Expenditure Ratios, Inflation Rate, Interest Rate of Bank Indonesia, Tax Ratio, Labor Force Change and Dollar Exchange Rate. The technique applied is the purposive sampling. The data used in this study is secondary data. Secondary data obtained from Central Bureau of Statistics, Bank of Indonesia and KOMPAS Daily Newspaper.

The method of analysis in this study using multiple regression analysis method and the deviation test against the classical assumption which includes multicolinearity test, autocoleration test, and heterokedastisity test.

In analyzing the factors influencing Indonesia's Economic Growth over the period $1997-2016$ :

\section{$\mathrm{Lg}$ PDB $=\alpha+\beta_{1} \mathrm{Lg}$ RPP $+\beta_{2} \mathrm{Lg}$ RT $+\beta_{3} \mathrm{Lg} \mathrm{RG}+\beta_{4} \mathrm{Lg}$ TI \\ $+\beta_{5} \mathrm{Lg} \mathrm{SBI}+\beta_{6} \mathrm{Lg} \mathrm{NTD}+\beta_{7}$ Lg RAK

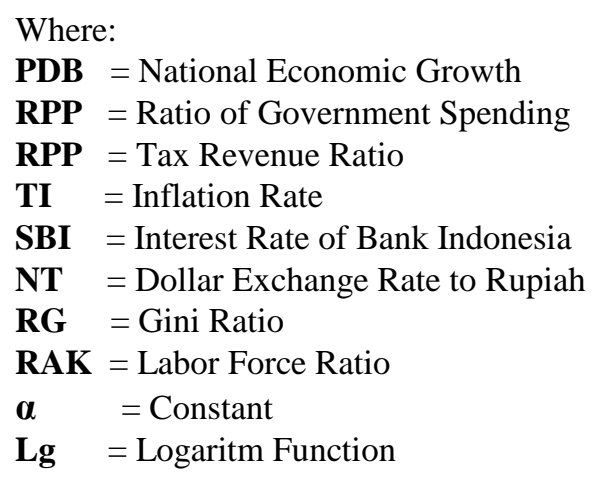

$\boldsymbol{\beta}_{\mathbf{1}}, \boldsymbol{\beta}_{\mathbf{2}}, \boldsymbol{\beta}_{\mathbf{3}}, \boldsymbol{\beta}_{\mathbf{4}} \boldsymbol{\beta}_{\mathbf{5}} \boldsymbol{\beta}_{\mathbf{6}} \boldsymbol{\beta}_{\mathbf{7}}$ : coefficient - coefficient

Gini Ratio, Government Expenditure Ratios, Inflation Rate, Interest Rate of Bank Indonesia, Tax Ratio, Labor Force Change and Dollar Exchange Rate are used as independent variables which are partially or simultaneously expected to affect Indonesia's Economic Growth over the period 1997 2016.

\section{RESUlT AND DisCUSSION}

\section{A. Simultaneous Test $(F)$ [Conformity Model]}

Based on the ANOVA or F test table the value of $F$ arithmetic obtained is 7.690 with a probability of 0.001 . Because the probability is less than 0,05 , it can be concluded that the regression coefficient of Gini Ratio (RG), Government Expenditure Ratio (RPP), Inflation Rate (TI), Interest Rate of Bank Indonesia (SBI), Ratio of Tax (RT), 
Changes Labor Force (RAK) and Dollar Exchange (NTD). or the seven independent or independent variables simultaneously affect the economic growth of Indonesia over the period 1997 - 2016. It also means the determination coefficient value of $\mathrm{R}^{2}$ is not equal to zero or significant. For more detail see Table 1.0 below:

Table 1.0 Simultaneous Significance Test (ANOVA)

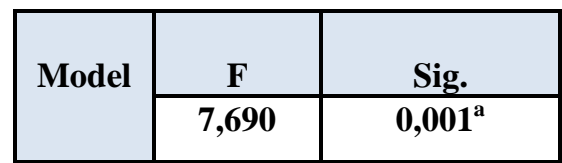

a. Predictors: (Constant), RPP,RT,RG,TI,SBI, NT,RAK

b. Dependent Variable: PDB

Source: Processed data (2018)

\section{B. Coefficient of Determination}

The external view of the SPSS model summary shows the volume of Square $R^{2}$ of 0.818 . This means that Indonesia's economic growth over the period 1997 - 2016 is as much as $81.8 \%$ it can be elaborated by the variation of seven independent or independent variables; Gini Ratio (RG), Government Expenditure Ratio (RPP), Inflation Rate (TI), Interest Rate of Bank Indonesia (SBI), Ratio of Tax (RT), Labor Force Change (RAK) and Dollar Exchange (NTD).

While the rest $(100 \%-81.8 \%=18.2 \%)$ is explained by other causes outside the model, Standard Error of Estimate [SEE] is 0.240069 , the smaller the value of SEE will make the regression model more precise in predicting dependent variables, for more details can be seen in Table 2.0 below:

Table 2.0. Coeficient of Determination

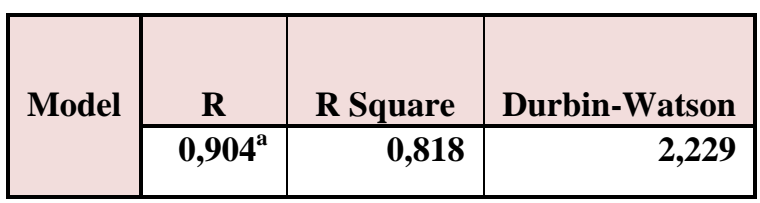

a. Predictors: (Constant), RPP,RT,RG,TI,SBI,NT,RAK

b. Dependent Variable:PDB

Source: Processed data (2018).

\section{Multiple Regression Equations}

To interpret the parameters coefficient of independent variables can be done unstandarized coefficients and standarized coefficients. From the seven independent or independent variables included in the model, there are only three (3) variables, namely the Interest Rate of Bank Indonesia (SBI) and the Government Expenditure Ratio (RPP), which is significant at $\alpha<5 \%$, it can be seen from the probability that the significance of both are far below 0,05 [SBI $=0,029<0,05 \& \mathrm{RPP}=0,035<0,05]$. The remaining five (5) independent variables of Gini Ratio (RG), Inflation Rate (TI), Tax Ratio (RT), Labor Force Change (RAK) and Dollar Exchange (NTD) are influential and insignificant due to $\alpha>5 \%$ where $\mathrm{RP}=0.49>0.05, \mathrm{RAK}=0.290>0.05 ; \mathrm{RG}=$ $0.184>0.05 ; \mathrm{TI}=0.184>0.05 ; \mathrm{NTD}=0.554>0.05$ For more details can be seen in Table 3 below:
Table 3.0 Partial Significance Test (t test).

\begin{tabular}{|l|c|c|c|c|c|}
\hline \multirow{2}{*}{ Model } & $\begin{array}{c}\text { Unstandardized } \\
\text { Coefficients }\end{array}$ & & & Level & Sign \\
\cline { 2 - 3 } \cline { 5 - 6 } & $\mathbf{B}$ & $\mathbf{t}$ & Sig. & $\begin{array}{c}\alpha<=5 \\
\%\end{array}$ & no \\
\hline (Constant) & $-1,037$ & $-0,152$ & 0,882 & $<5 \%$ & No \\
RT & $-0,443$ & $-0,712$ & 0,49 & $<5 \%$ & No \\
RPP & 3,120 & 2,370 & 0,035 & $<5 \%$ & Significant \\
RAK & $-0,196$ & $-1,107$ & 0,290 & $<5 \%$ & No \\
RG & $-8,103$ & $-1,411$ & 0,184 & $>5 \%$ & No \\
TI & $-0,347$ & $-1,411$ & 0,184 & $<5 \%$ & No \\
SBI & $-2,887$ & $-2,486$ & 0,029 & $>5 \%$ & Significant \\
NTD & 0,846 & 0,609 & 0,554 & $>\mathbf{5} \%$ & No \\
\hline
\end{tabular}

Depedend Variabel : PDB

Source: processed data (2018)

- The constant The constant coefficient is negative and insignificant, by assuming the absence of Gini Ratio (RG), Government Expenditure (RPP), Inflation (TI), Interest Rate (SBI), Ratio (RT), Labor Force Flow (RAK) and Dollar Exchange (NTD), the Indonesia Economic Growth over the period of 1997-2016 decreased 1,037 units.

- The regression coefficient of tax ratio (RT) is negative and insignificant, stating that by assuming the absence of other independent variables, if the Ratio of Tax (RT) has increased, then Indonesia's Economic Growth over the period 1997-2016 has decreased 0.443 units.

- The regression coefficient of the Government Expenditure Ratio (RPP) is positive and significant, assuming the absence of other independent variables. If the Government Expenditure Ratio (RPP) has increased, then Indonesia's Economic Growth in 1997-2016 has increased 3,120 Units.

- The regression coefficient of Labor Force (RAK) is negative and insignificant, by assuming the absence of other independent variables, if the labor force change (RAK) has increased, then the economic growth of Indonesia over the period 1997-2016 decreased 0.196 units.

- The regression coefficient of Gini Ratio (RG) is negative and insignificant, stating that by assuming the absence of other independent variables, if the Gini Ratio (RG) increases, then Indonesia's economic growth in 1997 - 2016 has decreased 8,103 Units.

- The regression coefficient of the Inflation Rate (TI), negative and insignificant, by assuming that there are no other independent variables, if the Inflation Rate (TI) has increased, then Indonesia's economic growth in 1997 - 2016 has decreased by 0.347 Units.

- The regression coefficient of Bank Indonesia Interest Rate (SBI) has positive and significant effect, by assuming the absence of other independent variables, if the interest rate of Bank Indonesia (SBI) has increased, then the Indonesia economic growth in 1997 - 2016 has decreased 2,887 Unit. 
The Impact of Indonesian Economic Growth on Tax Revenue Ratio, Goverment Expenditure Ratio and Macroeconomic Aspects in The Period of 1997-2016

- The regression coefficient of exchange rate (NTD) is negative and insignificant, by assuming the absence of other independent variables, if the Dollar Exchange (NTD) has increased, then Indonesia's Economic Growth over the period 1997-2016 has increased by 0.846 Units .

Therefore So it can be concluded that the variable of Indonesian economic growth over the period 1997-2016 is influenced by the Ratio of Government Expenditure (RPP) and the Interest Rate of Bank Indonesia (SBI), thus the multiple regression equation as the following:

$\log P D B=-1,037+3,120 \log R P P$ - 2,887 Log SBI

\section{Test Multicolinearity}

Multicollinearity test aims to test whether in the regression model occured a high or perfect correlation between independent variables. If there is a perfect multicolinearity between independent variable, then the regression coefficient of independent variable can not be determined and the standard error value becomes infinite. If the multicollinearity between independent variables is high, then the regression coefficient of independent variables can be determined but has a high standard error value means the regression coefficient value can not be estimated properly.

a). Based on table 4.0, it appears that RT has a CI value below 10, which means no multicollinearity, then for RPP and RAK has a CI value between 10 - 30 which means there is mild multicolinearity. Then other variable has a CI value above 30 indicating strong multicollinearity i.e. RG, TI, SBI and NTD.

b). Based on table 4.0, the RT, RPP, RAK, TI and NTD have tolerance values above 0.10 . it can be decided that there is no multicollinearity, while for Tolerance below 0.10 is RG (0.055) and SBI (0.053). It is conclusive there might be a mild multicollinearity. As for the VIF; Independent Variables; RT, RPP, RAK, TI and NTD below 10 VIF with Independent Variables; RT, RPP, RAK, TI and NTD, there can be no conclusion of multicolinearity. while for VIF above 10 is RG (18.225) \& SBI $(18,807)$. Conclusively, there might be a mild multicollinearity.

Tabel 4.0. Tolerance, VIF dan CI Independen Variabel

\begin{tabular}{|c|c|c|c|}
\hline \multirow{2}{*}{ Model } & \multicolumn{2}{|c|}{$\begin{array}{c}\text { Collinearity } \\
\text { Statistics }\end{array}$} \\
\cline { 2 - 3 } & & & \multirow{2}{*}{$\begin{array}{c}\text { Condition } \\
\text { Index }\end{array}$} \\
\cline { 2 - 3 } & Tolerance & VIF & 1,000 \\
(Constant) & & & 2,587 \\
RT & 0,141 & 7,091 & 10,645 \\
RPP & 0,342 & 2,928 & 18,486 \\
RAK & 0,124 & 8,070 & 31,128 \\
RG & 0,055 & 18,225 & 63,607 \\
TI & 0,292 & 3,423 & 6,711 \\
SBI & 0,053 & 18,807 & 96,711 \\
NTD & 0,146 & 6,844 & 439,729 \\
\hline
\end{tabular}

SourceData(2018)

\section{E. Autocorrelation Test}

Autocorrelation Autocorrelation test aims to test whether in a linear regression model there is correlation between residual errors in $t$ period with error in period $t-1$ (previous). If there is a correlation, then there is an autocorrelation problem. Autocorrelation arises because of sequential observations over time related to each other (Gujarati, 2012).

This problem arises because residuals are not free from one observation to another. This is often found in time series data because the disruption in a person / individual / group tends to affect the disruption of the same individual / group in the next period.

There are several ways that can be used to detect the presence of autocorrelation. One common ways of detecting autocorrelation in multiple linear regression is with Durbin Watson (DW) Test. D-W test is one of the most widely used test to determine whether or not there is autocorrelation. Almost all statistical programs already provide facilities to calculate the value of $d$ (which describes the DW coefficients). The $d$ value will be in the range of 0 to 4 , see the following table:

Almost all statistical programs already provide facilities to calculate the value of $d$ (which describes the DW coefficients). The $d$ value will be in the range of 0 to 4 , see the following table: : A-5a (Gujarati, 2012)

$\mathrm{n}=20 \& \mathrm{k}=7$ obtained $\mathrm{dL}=0,595 ; \mathrm{dU}=2,339$

\section{4-dU $<\mathrm{d}<4-\mathrm{dL} \rightarrow$ 4-2,339 $<2,229<4-0,595$ \\ $1,61<2,229<3,405$}

Based on the test results in Table 4.8. the equation of Multiple Regression Analysis the value of Durbin Watson (DW) obtained is $=2,229$. It means $d$ is between 1,61 and 3,405 then the conclusion of Total Cost SB Latex Industry in Indonesia in the period 1997 - 2016 that no decision or dubious $\rightarrow$ Ho; areas means no autocorrelation.

\section{F. Test Heteroscedasticity}

There are two ways of detecting the presence or absence of Heteroskedasticity, namely by the method of graphs and statistical methods. Graph method is usually done by looking at the plot graph between the predicted values of the dependent variable with the residual. While statistical methods can be used to identify the presence of Heteroskidasticity problems, some of these methods are Park Test, Glejser Test, Spearman Test, Goldfeld-Quandt Test, Bruesch-Pagan-Godfrey Test and White Test. But that will be discussed in this section only Graphs and Glejser Test methods.

Glejser Test. The results can be obsdrved in table 6.0. which clearly shows the overall variables, Gini Ratio (RG), Government Expenditure Ratio (RPP), Inflation Rate (TI), Interest Rate of Bank Indonesia (SBI), Ratio of Tax (RT), Labor Force Change (RAK) and Dollar Exchange Rate NTD, show significance value of all variables above 0.01 . There is no heteroscedasticity in this model, in other words all the independent variables contained in this model have the similar or homogeneous variant. 
Table. 6. Glejser Test Table which No Heteroscedastisity.

\begin{tabular}{|c|c|}
\hline Model & Sig \\
\cline { 2 - 3 } Constant & 0,881 \\
RT & 0,490 \\
RPP & 0,035 \\
RAK & 0,290 \\
RG & 0,183 \\
TI & 0,184 \\
SBI & 0,029 \\
NTD & 0,553 \\
\hline
\end{tabular}

Dependent Variable :AbsUi

Source:Processed Data(2018)

\section{CONCLUSION}

The Government Expenditure Ratio (RPP) and the Interest Rate of Bank Indonesia(SBI) significantly affected Indonesia's Economic Growth over the period 1997 - 2016.

The Government Expenditure Ratio (RPP) contributes positively and significantly, while the Interest Rate of Bank Indonesia (SBI) contributes negatively and significantly to the Indonesian economic growth over the period 1997 - 2016.

The Republic of Indonesia which home to more than 17,000 thousand islands with a population of nearly 250 million people, there was significant increase in the number of populations before and after the reformation movement. The most striking difference was the administration change form from centralized to decentralized government. This resulted in an increase in the number of provinces, districts and cities. The number of provinces of the New Order era were 27 provinces, after the reformation it became (thirty four) 34 provinces, as well as the number of regencies and municipalities from over 150 to nearly 300s.

Hence, they will burden the central government's expenditure not to mention the boost of the state budget over the period 1997 - 2017 resulted in greater government expenditure through the increase number of state civil apparatus, not to mention the employee expenditures, equipment and additions building and facilities. It is necessary for the government and the executive to conduct a moratorium in adding up provinces, districts and cities to control, supervise and take action in the budget arrangements either in the central government or regency / city government. Large government expenditures will have a direct impact on national economic growth, if they are not in compliance with the import and export volume and other sources of revenue which will give significant influence.

\section{REFERENCES}

[1] Arsyad, L. 2014 . Industrial Economics Approach to Structure, Behavior and Performance. UP STIE YKPN, Yogyakarta

[2] BPS Indonesia, 1995 - 2017. .Macroeconomic Report Annually. Magazine on Indonesia Statiscal Datas, Vol. 4, No. 4.

[3] Gujarati, 2010. Macroeconomics Econometry, Mc-Graw Hill Book, New York, USA

[4] Mankiw, 2007. Principles of Economics, Fourth-Edition, Cameron University,New York, USA

[5] Nugroho, R..E, 2017. Strategic Macroeconomic Factors Affecting the Price of Styrene Butadiene Latex in Indonesia, Journal of Science Management UNSERA, Vol.2, No.1
[6] Nugroho, R..E, 2017. Analysis of Factors Affecting Economic Growth in Banten Province Dynamics and Control, Second Edition, Wiley International Edition, New Jersey, USA.

Rosalendro Eddy Nugroho is currently a fulltime senior lecturer in Master Program in Post-Graduate Management from Universitas Mercu Buana Jakarta. He holds a Bachelor of Science degree in Chemichal Engineering from Gadjah Mada University, Master of Management from Universitas Satyagama Jakarta, and $\mathrm{PhD}$ in Management from Bogor Agriculture University. He has taught courses in operation management, supply chain management, enterprise resource planning, and managerial economic. 